\title{
ASSOCIATION OF DENTAL CARIES AND ORAL HEALTH RELATED QUALITY OF LIFE (OHRQOL) IN DISABLED CHILDREN
}

\author{
Rubab Jawed, Zohaib Khan*, Maryam Younus**, Khadijah Abid**, Momina Saleem***, Zeeshan Kibria* \\ Baqai Dental College, Karachi Pakistan, * Khyber Medical University, Peshawar Pakistan, ${ }^{* *}$ College of Physician and Surgeon Pakistan, Karachi Pakistan, \\ ***Khyber College of Dentistry, Peshawar Pakistan
}

\begin{abstract}
Objective: To assess the association of dental caries and oral health related quality of life in mentally or physical disabled children studying in schools of Karachi.

Study Design: Cross sectional study.

Place and Duration of Study: Public and private sector special needs schools of Karachi, from Sep to Nov 2017.

Methodology: This study was conducted on 196 disabled children (mental/physical) in Karachi Pakistan. Children aged 6-18 years and having a disability was included in the study. We calculated the prevalence of dental caries through an examination of the oral cavity using the Decayed, missing and filled teeth index. Data were analyzed in SPSS version 20.

Results: Dental caries was found in 114 (58.2\%). "Oral symptoms" score was (4.46 \pm 0.85 vs. $4.95 \pm 0.79 ; p<0.001)$, "functional limitation" (4.12 \pm 1.0 vs. $4.63 \pm 0.82 ; p<0.001)$, "emotional wellbeing" (4.40 \pm 0.92 vs. $4.97 \pm 0.70 ; p<0.001)$ and "parental distress and family function" (3.65 \pm 0.97 vs. $4.03 \pm 0.96 ; p<0.001)$ in children with and without dental caries respectively. All the oral health related quality of life score domains showed statistically significant association between mentally and physical disabled children with and without dental caries.

Conclusion: All the oral health related quality of life related domains had a significant negative impact on the quality of life in mentally and physical disabled children.

Keywords: Dental caries, Down syndrome, Decayed, Missing and filled teeth index, Mental disabilities, Oral health related quality of life.

This is an Open Access article distributed under the terms of the Creative Commons Attribution License https://creativecommons.org/licenses/by-nc/4.0/), which permits unrestricted use, distribution, and reproduction in any medium, provided the original work is properly cited.
\end{abstract}

\section{INTRODUCTION}

A wide range of hereditary or genetic conditions like cerebral palsy, Down's syndrome, hearing problems, visual impairments, autism, epilepsy, and psychiatric or psychological disorders lead to disabilities in an individual ${ }^{1}$. The World Health Organization (WHO) reports that over 500 million people worldwide are living with some form of disability ${ }^{2}$. A WHO report recognized that oral diseases cause pain, suffering, psychological constraints, and social deprivation, resulting in loss of individuals and society ${ }^{3}$. The oral manifestations associated with disabilities are changes in the structure of the Oro-facial region, development of parafunctional behaviors like swallowing and drooling problems, and difficulties in maintaining acceptable levels of oral hygiene ${ }^{4}$.

Dental caries is the world's most prevalent disease in children with disabilities, and dental treatment is the disable's greatest unattended need for protection. Some of the main reasons may be inadequate sessions, socioeconomic status, underestimation of treatment needs or pain, problems of communication and poor cooperation $^{5}$. Mentally and physically challenged in-

Correspondence: Maryam Younus, Senior Statistician, College of Physician and Surgeons Pakistan, Karachi Pakistan

Received: 04 Feb 2020; revised received: 13 May 2020; accepted: 29 May 2020 dividuals have compromised neuromuscular function, impaired genetics and disturbed nutrition often resulting in dental caries at a younger age in comparison to healthy children. Additionally, the severity of caries is also higher in the disable children and is attributed to an increased bacterial load. Bacterial plaque is one of the main causes of dental caries. Poor oral hygiene and periodontal disease are significantly associated with mentally disable children. Moreover compromised dexterity in these children leads to progressive destruction of oral tissues. Despite the compromised oral health in disabled children, the treatment and care for them has traditionally been neglected ${ }^{5,6}$. Oral health is an indicator of overall health. Functions such as chewing, digestion, speech and appearance are affected by an impaired oral health ${ }^{7}$.

Locker suggested that problems related to oral health can affect quality of life, but these effects are not predictable as such. Such conditions also affect the quality of life (QoL) of the individual. Oral health problems have increasingly been identified as important factors that have a negative impact on everyday performance and quality of life as they influence how people grow, enjoy life, speak, chew, taste food and socialize ${ }^{8}$. Oral health contributes to an individual's overall health, self-esteem, and quality of life. Several recent 
research of children with mental challenges have documented relatively poor oral hygiene and high levels of periodontal disease ${ }^{1}$.

Compared to normal children, literature on the dental management of disabled children is scarce. Until recent years, in the undergraduate curriculum of most dental schools in different parts of the world, the management of disabled children was not even listed. There is a lack of literature among mentally and physically disabled children in Pakistan on dental caries and oral health-related quality of life. To promote oral health, analyzing the behavior of oral health and its influencing factors is important. The research therefore aimed to evaluate the correlation between the current status of oral health-related quality of life and the experience of dental caries among children with special needs. With more recent developments in this area, this information is important for dental practitioners to prepare care for disabled people and also to help other health professionals understand the oral health status of children with mental and physical disabilities. Furthermore, the evaluation of OHRQoL would be useful in drawing attention to how oral health-related issues affect the daily lives of children with mental or physical disabilities in order to prioritize oral health care measures.

\section{METHODOLOGY}

We performed a cross-sectional study in Karachi's special needs schools in the public and private sectors from September to November 2017. The sample size was calculated using an online software www.openepi. com with the proportion of dental caries $93 \%$ in special need children 9 , and confidence level of $95 \%$ and margin of error set at $5 \%$. The sample size calculated was 101 but we included 196 subjects.

The study participants were selected on the basis of multistage stratified random sampling. In the first phase, two public sector and two private sector special children schools were randomly selected from the list of all schools obtained from the education department (total 8 private sector and 4 public sector special children schools). In the second phase, administrative permission was obtained from the heads of selected public and private sector special children school. The sampling frame was developed after obtaining the complete list of students in both public and private sector schools. After developing the special children list (total 132 children in public sector and total 580 in the private sector), random selection of the study participants were done proportionately from both public and private sector schools (37 from public sector and 159 from private sector).

Ethics approval for the study was granted by Khyber Medical University Ethics Committee having ltr no. DIR/KMI-AS \& RB/PD/000650. The parents of the participants were given an orientation to the study via a study information sheet and were assured that the data is meant only for research purpose and confidentiality will be observed regarding all data and records. Informed consent was obtained from the parents /guardians and approval was taken from the school authorities before the subjects were included in the study. Children (both male and female) 6-18 years of age suffering from various types of disabilities i.e. intellectual disabilities (ID), Deaf or hard of hearing, Down syndrome (DS), autistic, vision impairment and cerebral palsy were included. Children with disabilities having a mouth opening $<30 \mathrm{~mm}$ were excluded from the study because with limited mouth opening it is difficult to examine the oral cavity.

We recorded dental caries by using the decayed missing and filled teeth (DMFT) index. The sum of the three figures (DMF) forms the DMFT value. A structured questionnaire was sent to the parents to obtain the general information about child i.e. name, age, type of disability, demographic characteristics of the parents and other questions in the questionnaire were related to the oral hygiene practices of the child and awareness of dental problems and the effects of fluoride on dentition among the parents.

Dental checkup of the participants was conducted at their respective schools. Illumination was provided using artificial light (torch) and dental checkup was carried out by using disposable dental kit consisting of a mouth mirror, dental probe, tweezers, napkin, and cotton rolls. Those participants who were physically disabled were examined on their wheelchairs. All examinations were carried out by a single dentist (principal investigator). The parents/guardians were informed about the clinical findings through written information sheets made for the school record. Following the examination, oral health education was given, in addition to referrals to dental clinics, whenever these were deemed necessary.

OHR QoL questionnaire included oral symptoms, functional limitations, emotional well-being, family well-being, and parent's reported apparent oral health symptoms of their child within the last 3 months for each dimension. Each of the four domains is scored by averaging the items in that domain. The responses are 
never $=1$, once or twice $=2$, sometimes $=3$, often $=4$, and everyday $=5$.

Data were recorded and analyzed through SPSS20. Descriptive statistics were computed for study variables including demographics and other charecterstics of study subjects. Independent t-test was applied to achieve the study objective at $p$-value $\leq 0.05$ as significant.

\section{RESULTS}

A total of 196 subjects were included in this study out of total males were 127 (64.8\%) while females were $69(35.2 \%)$ in our study, children were mostly in the age category of 6-13 years 117 (59.7\%). The mean age of the sample was $12.18 \pm 3.89$ years. Majority of the children belong to Muslim families 187 (95.4\%). Most of the children $84(42.9 \%)$ in our study were intellectually disabled, 41 (20.9\%) were deaf, down syndrome was recorded in $31(15.8 \%)$ and $40(20.4 \%)$ had other disabilities showed in table-I.

Table-I: Baseline characteristics ( $n=196)$.

\begin{tabular}{|c|c|c|}
\hline Baseline Characteristics & Frequency & Percentage \\
\hline \multicolumn{3}{|l|}{ Gender of Child } \\
\hline Male & 127 & 64.8 \\
\hline Female & 69 & 35.2 \\
\hline Age of Child & \multicolumn{2}{|c|}{$12.18 \pm 3.897$ Years } \\
\hline $6-13$ years & 117 & 59.7 \\
\hline$>13-18$ years & 79 & 40.3 \\
\hline \multicolumn{3}{|l|}{ Religion } \\
\hline Islam & 187 & 95.4 \\
\hline Christian & 9 & 4.6 \\
\hline \multicolumn{3}{|l|}{ School Type } \\
\hline Private & 159 & 81.1 \\
\hline Public & 37 & 18.9 \\
\hline \multicolumn{3}{|l|}{ Type of Disability } \\
\hline Deaf or hard of hearing & 41 & 20.9 \\
\hline Intellectual disability & 84 & 42.9 \\
\hline Down syndrome & 31 & 15.8 \\
\hline Others & 40 & 20.4 \\
\hline \multicolumn{3}{|l|}{ Dental Caries } \\
\hline Present & 114 & 58.2 \\
\hline Absent & 82 & 41.8 \\
\hline
\end{tabular}

Dental caries was assessed by DMFT/dft score and it was found that more than half 114 (58.2\%) children had dental caries (table-II). The prevalence of dental caries was highest among the children with down syndrome $(67.7 \%)$ with mean DMFT/dft score $2.45 \pm$ 2.65 followed by children with intellectual disability (61.9\%) with mean DMFT/dft score $1.70 \pm 2.01$, children with hearing problems $(46.3 \%)$ with mean DMFT/ $\mathrm{dft}$ score $1.49 \pm 2.27$ and children with other disabilities (55\%) with mean DMFT/dft score $2.05 \pm 2.51$.
Table-II: Dental caries and decay-missing-filled teeth/ decay-filled teeth score among different type of disabilities.

\begin{tabular}{l|c|c}
\hline $\begin{array}{l}\text { Type of } \\
\text { Disability }\end{array}$ & $\begin{array}{c}\text { Dental } \\
\text { Caries }\end{array}$ & $\begin{array}{c}\text { Mean of decay missing } \\
\text { filled teeth/ decay filled } \\
\text { teeth (DMFT/dft) score }\end{array}$ \\
\hline $\begin{array}{l}\text { Deaf or Hard } \\
\text { of hearing }\end{array}$ & $19(46.3 \%)$ & $1.49 \pm 2.27$ \\
\hline $\begin{array}{l}\text { Intellectual } \\
\text { Disability }\end{array}$ & $52(61.9 \%)$ & $1.70 \pm 2.01$ \\
\hline $\begin{array}{l}\text { Down } \\
\text { Syndrome }\end{array}$ & $21(67.7 \%)$ & $2.45 \pm 2.65$ \\
\hline Others & $22(55 \%)$ & $2.05 \pm 2.51$ \\
\hline
\end{tabular}

Oral health related QoL scores i.e. oral symptoms, functional limitations, emotional wellbeing, family wellbeing, parents reported apparent oral health symptoms of their child within the last 3 months for each dimension. Frequencies of each response are summarized in the table-III. With regards to oral symptoms related quality of life, most of the children reported with pain $(35.2 \%)$, bleeding gum $(23.5 \%)$, sores in the mouth $(30.6 \%)$, bad breath $(32.7 \%)$, food impaction between the teeth $(41.2 \%)$ and difficulty in chewing and biting $(20.9 \%)$ sometimes in their routine. Only $8(4.1 \%)$ and 6 $(3.1 \%)$ children had problem of bad breath and difficulty in chewing and biting every day. Functional limitations also showed the same pattern like oral symptoms where more than half of the population had not observed such limitations. Whereas limitations like difficulty in breathing, troubled sleep, sensitivity, difficulty in eating and restricted diet was noted in $52(26.5 \%), 32(16.3 \%), 41(20.9 \%), 48(24.3 \%)$ and 42 $(21.4 \%)$ respectively sometimes in their daily routine. Findings also showed that 69 (35.2\%) children faced difficulty in saying word and $47(24 \%)$ children took longer time to eat meal. Assessment of emotional wellbeing stated that $42(21.9 \%)$ subjects of the study felt upset sometimes in their regular routine. Almost 40\% of the children never fell irritable or frustrated while $66(33 \%)$ felt that sometimes and $37(18.9 \%)$ often felt that. Anxiousness and fearfulness was recorded in $60 \%$ children in our study. Parental distress and family function domains showed 89 (45.4\%) parents never got upset with this situation. One hundred and nineteen $(60.7 \%)$ had disturbed sleep, $25(12.8 \%)$ parents felt guilty, $1 / 3$ of them worried about having less opportunities for their children and $100(49 \%)$ of them felt uncomfortable in public place while $56(28.6 \%)$ felt this sometimes.

Table-IV shows that all oral health related quality of life domains scores were compared between chil- 
dren with or without having dental caries. Mean Oral symptoms score in with and without dental caries children was $(4.46 \pm 0.85$ vs. $4.95 \pm 0.79 ; p<0.000)$, functio- score $(3.65 \pm 0.97$ vs. $4.03 \pm 0.96 ; p=0.008)$. This signifies that OHRQoL of children without caries was better than with caries.

Table-III: Assessment of oral health related quality of life.

\begin{tabular}{|c|c|c|c|c|c|c|}
\hline Oral Symptoms & Never & $\begin{array}{l}\text { Once or } \\
\text { twice }\end{array}$ & Sometimes & Often & Everyday & $\begin{array}{l}\text { Don't } \\
\text { Know }\end{array}$ \\
\hline Pain in teeth, lips, jaws or mouth & $102(52 \%)$ & $12(6.1 \%)$ & $69(35.2 \%)$ & $13(6.6 \%)$ & - & NA \\
\hline Bleeding gums & $131(66.8 \%)$ & $11(5.6 \%)$ & $46(23.5 \%)$ & $7(3.6 \%)$ & $1(0.5 \%)$ & NA \\
\hline Sores in the mouth & $99(50.5 \%)$ & $13(6.6 \%)$ & $60(30.6 \%)$ & $23(11.7 \%)$ & $1(0.5 \%)$ & NA \\
\hline Bad breath & $92(46.9 \%)$ & $6(3.1 \%)$ & $64(32.7 \%)$ & $26(13.3 \%)$ & $8(4.1 \%)$ & NA \\
\hline Food stuck in the roof of mouth & $148(75.7 \%)$ & $6(3.1 \%)$ & $30(15.3 \%)$ & $10(5.1 \%)$ & $2(1 \%)$ & NA \\
\hline Food caught in or between the teeth & $83(42.3 \%)$ & $10(5.1 \%)$ & $82(41.2 \%)$ & $19(9.7 \%)$ & $2(1 \%)$ & NA \\
\hline Difficulty in biting or chewing & $92(46.9 \%)$ & $7(3.6 \%)$ & $41(20.9 \%)$ & $50(25.5 \%)$ & $6(3.1 \%)$ & NA \\
\hline Functional Limitations & Never & $\begin{array}{l}\text { Once or } \\
\text { twice }\end{array}$ & Sometimes & Often & Everyday & $\begin{array}{l}\text { Don't } \\
\text { Know }\end{array}$ \\
\hline Breathed through the mouth & $92(46.9 \%)$ & $7(3.6 \%)$ & $52(26.5 \%)$ & $32(16.3 \%)$ & $13(6.6 \%)$ & NA \\
\hline Had trouble sleeping & $138(70.4 \%)$ & $3(1.5 \%)$ & $32(16.3 \%)$ & $15(7.7 \%)$ & $8(4.1 \%)$ & NA \\
\hline Had difficulty saying any words? & $52(26.5 \%)$ & $2(1 \%)$ & $36(18.4 \%)$ & $69(35.2 \%)$ & $37(18.9 \%)$ & NA \\
\hline $\begin{array}{l}\text { Took Longer time to eat a meal than } \\
\text { others? }\end{array}$ & $77(39.3 \%)$ & $5(2.6 \%)$ & $27(13.8 \%)$ & $47(24 \%)$ & $40(20 \%)$ & NA \\
\hline $\begin{array}{l}\text { Hot or cold food was difficult in eating } \\
\text { and drinking }\end{array}$ & $118(60.2 \%)$ & $4(2 \%)$ & $41(20.9 \%)$ & $25(12.8 \%)$ & $8(4.1 \%)$ & NA \\
\hline $\begin{array}{l}\text { Foods he/she would like to eat was } \\
\text { difficult to eat }\end{array}$ & $112(57.1 \%)$ & $3(1.5 \%)$ & $48(24.3 \%)$ & $15(7.7 \%)$ & $9(4.6 \%)$ & NA \\
\hline $\begin{array}{l}\text { Had restricted diet } \\
\text { (for example: soft food)? }\end{array}$ & $118(60.2 \%)$ & $5(2.6 \%)$ & $42(21.4 \%)$ & $15(7.7 \%)$ & $16(8.2 \%)$ & NA \\
\hline Emotional wellbeing & Never & $\begin{array}{l}\text { Once or } \\
\text { twice }\end{array}$ & Sometimes & Often & Everyday & $\begin{array}{l}\text { Don't } \\
\text { Know }\end{array}$ \\
\hline Upset & $111(56.6 \%)$ & $10(5.1 \%)$ & $43(21.9 \%)$ & $21(10.7 \%)$ & - & $11(5.6 \%)$ \\
\hline Irritable or frustrated & $74(37.8 \%)$ & $3(1.5 \%)$ & $66(33.7 \%)$ & $37(18.9 \%)$ & $10(5.1 \%)$ & $6(3.1 \%)$ \\
\hline Anxious or fearful & $81(41.3 \%)$ & $7(3.6 \%)$ & $55(28.1 \%)$ & $39(19.9 \%)$ & $5(2.6 \%)$ & $9(4.6 \%)$ \\
\hline Parental Distress and Family Function & Never & $\begin{array}{l}\text { Once or } \\
\text { twice }\end{array}$ & Sometimes & Often & Everyday & $\begin{array}{l}\text { Don't } \\
\text { Know }\end{array}$ \\
\hline Parents upset & $89(45.4 \%)$ & $6(3.1 \%)$ & $62(31.6 \%)$ & $32(16.3 \%)$ & $3(1.5 \%)$ & $4(2 \%)$ \\
\hline Parent's sleep disturbed & $119(60.7 \%)$ & $4(2 \%)$ & $43(21.9 \%)$ & $21(10.7 \%)$ & $8(4.1 \%)$ & $1(0.5 \%)$ \\
\hline Parent's felt guilty & $145(74 \%)$ & - & $25(12.8 \%)$ & $11(5.6 \%)$ & $1(0.5 \%)$ & $14(7.1 \%)$ \\
\hline Taken off from work & $120(61.2 \%)$ & $10(5.1 \%)$ & $43(21.9 \%)$ & $13(6.6 \%)$ & $1(0.5 \%)$ & $9(4.6 \%)$ \\
\hline Less time for yourself or family & $116(59.2 \%)$ & $5(2.6 \%)$ & $37(18.9 \%)$ & $23(11.7 \%)$ & $3(1.5 \%)$ & $12(6.1 \%)$ \\
\hline $\begin{array}{l}\text { Worried that child will have less } \\
\text { opportunity }\end{array}$ & $55(28.1 \%)$ & $2(1 \%)$ & $58(29.6 \%)$ & $61(31.1 \%)$ & $17(8.7 \%)$ & $3(1.5 \%)$ \\
\hline Uncomfortable in public places & $100(51 \%)$ & $3(1.5 \%)$ & $56(28.6 \%)$ & $34(17.3 \%)$ & $2(1 \%)$ & $1(0.5 \%)$ \\
\hline
\end{tabular}

Table-IV: Oral health related quality of life and dental caries.

\begin{tabular}{l|c|c|c|c}
\hline \multirow{2}{*}{ Domain } & \multirow{2}{*}{$\begin{array}{c}\text { Overall } \\
\text { Mean Score }\end{array}$} & Present (n=114) & Absent (n=82) & $p$-value \\
\cline { 3 - 5 } & $4.0 \pm 1.14$ & $4.46 \pm 0.85$ & $4.95 \pm 0.79$ & $<0.001$ \\
\hline Oral Symptoms & $3.65 \pm 1.39$ & $4.12 \pm 1.0$ & $4.63 \pm 0.82$ & 0.001 \\
\hline Functional Limitations & $3.81 \pm 1.25$ & $4.40 \pm 0.92$ & $4.97 \pm 0.70$ & $<0.001$ \\
\hline Parental Distress and Family Function & $3.98 \pm 1.19$ & $3.65 \pm 0.97$ & $4.03 \pm 0.96$ & 0.008 \\
\hline
\end{tabular}

Independent $t$-test applied. $p$-value $\leq 0.05$ Significant.

nal limitations score $(4.12 \pm 1.0$ vs. $4.63 \pm 0.82 ; p=0.001)$, emotional wellbeing score $(4.40 \pm 0.92$ vs. $4.97 \pm 0.70$; $p<0.000)$ and parental distress and family function

\section{DISCUSSION}

The incapacitated individuals has to face many problems in order maintain their life quality. The mai- 
ntenance becomes challenging when there is inaccessibility of proper oral care. Traditionally, periodontal disease develops when individuals have to compromise their oral hygiene. With compromise health, oral health is also affected. Loss of control to hold tooth brush had negative impact on overall quality of life ${ }^{6}$. Thus according to this study, the main objective is to compare the mean OHRQoL score with dental caries in mentally disabled school going children.

The results of present study showed dental caries was highest among the children with down syndrome (67.7\%) with mean DMFT/dft score $2.45 \pm 2.65$ whereas other study reported that $90 \%$ disabled patients had dental caries ${ }^{10}$. In other Pakistani study, the occurrence of dental caries in mentally disabled children was around $48 \%{ }^{11}$. The findings of this study are similar with another study by Makkar et al12. Dheepthasri et al13, concluded in his study that individuals with intellectual disability were found to have compromised oral health however the almost $58 \%$ of the individuals had their oral hygiene maintained. Maintaining good oral health for people with disabilities is particularly challenging due to raised oral health risks because of underlying disease, limits on access to care, and competing demands. The lack of oral hygiene has been involved in the development of periodontal diseases and dental caries in subjects with ID as a fundamental factor. Regular care special schools have been included in this analysis to assess the oral health of the subjects from the natural home setup. Bhowate $e^{2}$ all ${ }^{14}$, also reported similar results regarding oral hygiene status of mentally challenged individuals. Reddy et al, had studied DMFT score in cases and controls and concluded that cases had higher risk of developing caries up to $80 \%$. This could be because of impaired oral health function, lack of neuromuscular coordination. In addition, the cases had increase consumption of sugary food ${ }^{15}$.

In another study, mean DMFT score was quite higher as compare to results of our study ${ }^{16}$, however, in contrast to another study by Kamatchy et $a l^{17}$. DMFT score was lesser as compare to current study.

A dentist goal for management of disabled children should be optimal oral hygiene. This is because these children have compromised immunity that leads to progressive destruction of dental tissues with even small amount of plaque. There is reportedly an increase level of MMPs in down syndromic individuals. Increase MMPS leads to greater destruction of periodontal tissue causing individuals to suffer from exten- sive bone $\operatorname{loss}^{18}$. In the light of this statement, the findings of current study showed that $23.5 \%$ of disabled children had their gums bleed, $32.7 \%$ of children had bad breath and $20.9 \%$ had difficulty in chewing and biting. This explains risk factors towards development of periodontal disease also explained by Kosaka et al, similarly data regarding children with cerebral palsy reported poor OHRQoL. Only dental caries experience and bruxism showed an association with the overall OHRQoL score among all oral diseases and disorders evaluated in this study. Although the history of dental caries and certain socio-economic factors are strongly associated with the negative impact of children with $\mathrm{CP}$ on OHRQoL. It is necessary to further investigate the influence of certain characteristics of individuals with $\mathrm{CP}$, such as severity of cognitive ability, motor ability and clinical type of $\mathrm{CP}^{20,21}$.

In the present study, OHRQol tool showed that $4.1 \%$ disabled children had halitosis. That means there is higher number of anaerobicd bacteria in their saliva or gingival clavicular fluid that further damages their oral tissues ${ }^{22}$. In $41.2 \%$ mentally challenged children had complained about food wedge between their teeth. Sometimes and $16.6 \%$ has developed ulcers in their mouth once or twice. The results explains and highlights the fact that mouth breathing, food impaction, ulcers are risk factors leading to compromised oral healthy quality. It is also worth noticing that due to functional limitation in these children $20 \%$ had to take longer time to finish their meals and $35.2 \%$ had often speech problems. About $26.5 \%$ were mouth breathers which are also explained by de Castilho et al ${ }^{23}$. It is also important to determine emotional needs of these children as $66 \%$ of the children were sometimes irritable and $39 \%$ had anxiety often that is also recently reported by Van et $a l^{24}$. Mental conditions greatly affect over wellbeing. Moreover the family support found to be significantly associated with dental caries. There were $31.6 \%$ parents remain upset sometimes because of their children wellbeing. Ther were $17.3 \%$ parents were uncomfortable in public places often. This shows that it is great responsibility to be a parent or caregiver of these children. The guardian also needs support and appreciation during their care provision along with the children. Literature has also revealed some factors causing a gap for inadequate health care provision in disable children by highlighting few factors for example: lack of proper resources to provide optimal care, inability of health care professionals to give adequate amount of time to understand and remodel disabled children 
behavior, scarcity of knowledge for mentally challenged students ${ }^{25}$.

\section{CONCLUSIONS}

In children with special care needs, there is a significantly high dental caries burden, especially in children with mental disabilities. The results reflect a fact that the oral health quality of life in children with disabilities is severely compromised. The association between oral health quality of life and dental caries is statistically significant. DMFT/dft score was the highest in the DS and the lowest in the Deaf or hard to hear.

\section{CONFLICT OF INTEREST}

This study has no conflict of interest to be declared by any author.

\section{REFERENCES}

1. Tesini DA, Fenton SJ. Oral health needs of persons with physical or mental disabilities. Dent Clin North Am 1994; 38(3): 483-98.

2. Krahn GL. WHO World Report on Disability: a review. Disabil Health J 2011; 4(3): 141-2.

3. Gomes AS, Abegg C. The impact of oral health on daily performance of municipal waste disposal workers in Porto Alegre, Rio Grande do Sul State, Brazil. Cad Saude Publica 2007; 23(7): 170714.

4. Dougherty NJ. A review of cerebral palsy for the oral health professional. Dent Clin North Am 2009; 53(2): 329-8.

5. Hennequin M, Faulks D. Accuracy of estimation of dental treatment need in special care patients. J Dent 2000; 28(2): 131-6.

6. Franks A, Winter GB. Management of the handicapped and chronic sick patient in the dental practice. Brit Dent J 1974; 136(4): 145-50.

7. Saravane D, Feve B, Frances Y, Corruble E, Lancon C, Chanson P, et al. Drawing up guidelines for the attendance of physical health of patients with severe mental illness. L'Encephale 2009; 35(4): 330-9.

8. Locker D. Concepts of oral health, disease and the quality of life. Measur Oral Health Qual Life 1997; 11(1): 24-28.

9. Al-Maweri SA, Zimmer S. Oral health survey of 6-14-year-old children with disabilities attending special schools Yemen. J Clin Pediatr Dent 2015; 39(3): 272-6.

10. Kalia S, Shetty SK, Patil K, Mahima V. Stature estimation using odontometry and skull anthropometry. Ind J Dent Res 2008; 19(2): 150-5.

11. Rehman MKR, Zehra A, Syeda K, Fatima N. Oral health and general health in children having intellectual disabilities: a cross sectional study. J Islamic Int Med Coll 2015; 4(10): 242-5.

12. Makkar A, Indushekar KR, Saraf BG, Sardana D, Sheoran N. A cross sectional study to evaluate the oral health status of children with intellectual disabilities in the National Capital Region of India (Delhi-NCR). J Intellect Disabil Res 2019; 63(1): 31-39.

13. Dheepthasri S, Taranath M, Garla BK, Karuppaiah M, Sangeeta $\mathrm{U}$. Oral health status and treatment needs among intellectually disabled in Madurai. J Adv Oral Res 2018; 9(1-2): 45-8.

14. Bhowate R, Dubey A. Dentofacial changes and oral health status in mentally challenged children. J Ind Soc Pedod Prev Dent 2005; 23(2): 71-3.

15. Reddy K, Sharma A. Prevalence of oral health status in visually impaired children. J Ind Soc Pedod Prev Dent 2011; 29(1): 25-7.

16. Ivančić Jokić N, Majstorović M, Bakarčić D, Katalinić A, Szirovicza L. Dental caries in disabled children. Coll Antropol 2007; 31(1): 321-4.

17. Kamatchy K, Joseph J, Krishnan C. Dental caries prevalence and experience among the group of institutionalized hearing impaired individuals in Pondicherry - a descriptive study. Ind J dent Res 2003; 14(1): 29-32.

18. Tsilingaridis G, Yucel-Lindberg T, Concha Quezada H, Modéer $\mathrm{T}$. The relationship between matrix metalloproteinases (MMP $3,8,9)$ in serum and peripheral lymphocytes (CD 8+, CD 56+) in Down syndrome children with gingivitis. J Periodont Res 2014; 49(6): 742-50.

19. Kosaka M, Senpuku H, Hagiwara A, Nomura Y, Hanada N. Oral infection, periodontal disease and cytokine production in adults with Down syndrome. Med Res Arch 2017; 5(3): 1-5.

20. Abanto J, Ortega AO, Raggio DP, Bönecker M, Mendes FM, Ciamponi AL. Impact of oral diseases and disorders on oralhealthrelated quality of life of children with cerebral palsy. Spec Care Dentist 2014; 34(2): 56-63.

21. El Ashiry EA, Alaki SM, Nouri SM. Oral Health Quality of Life in Children with Cerebral Palsy: Parental Perceptions. J Clin Pediatr Dent 2016; 40(5): 375-87.

22. Wang F, Qiao W, Bao B, Wang S, Regenstein J, Shi Y, et al. Effect of IgY on Periodontitis and Halitosis Induced by Fusobacterium nucleatum. J Microbiol Biotechnol 2019; 29(2): 311-20.

23. de Castilho LS, Abreu MH, de Oliveira RB, Souza E, Silva ME, Resende VL. Factors associated with mouth breathing in children with-developmental-disabilities. Spec Care Dentist 2016; 36(2): 75-9.

24. van Steensel FJA, Heeman EJ. Anxiety levels in children with autism spectrum disorder: a meta-analysis. J Child Fam Stud 2017; 26(7): 1753-67.

25. Brown JP, Schodel DR. A review of controlled surveys of dental disease in handicapped persons. ASDC J Dent Child 1976; 43(5): 313-20. 